\title{
From the American to the European amphioxus: towards experimental Evo-Devo at the origin of chordates
}

\author{
JORDI GARCIA-FERNÀNDEZ*, SENDA JIMÉNEZ-DELGADO, JUAN PASCUAL-ANAYA, IGNACIO MAESO, \\ MANUEL IRIMIA, CAROLINA MINGUILLÓN1', ĖLIA BENITO-GUTIÉRREZ², JOSEP GARDENYES³, \\ STÉPHANIE BERTRAND and SALVATORE D'ANIELLO
}

Departament de Genètica, Facultat de Biologia, Universitat de Barcelona, Spain

\begin{abstract}
Pallid anchovy fillet, friendly filtering, peacefully laying and little lancelet are some of the nicknames and adjectives the cephalochordate amphioxus has received throughout the last two centuries. Traditionally regarded as the living representative of the last ancestor of vertebrates, amphioxus has recently been promoted to the privileged position of being the most ancient chordate. The preliminary analysis of its prototypical genome is nearly completed, and its hidden secrets towards the understanding of the primitive chordate and deuterostome genomes will soon see the light. Amphioxus embryonic development and body plan have remained in evolutionary stasis since the cephalochordate lineage split from the chordate ancestor about $\mathbf{5 0 0}$ million years ago. In contrast, amphioxus research is far from being at a standstill; in Europe, thanks to the international cooperation and the Banyuls Oceanographic Station, amphioxus embryos are obtained on demand during the spawning season. We summarise here our progress towards the dream of the experimental manipulation of the amphioxus embryo, to enter the era of Experimental Evo-Devo.
\end{abstract}

KEY WORDS: amphioxus, Evo-Devo, chordate, gene duplication, vertebrate

Commonality of embryonic structure reveals community of descent. As simple as it sounds today, the striking sentence of Charles Darwin (1859) highlighting the importance of embryonic development to indicate evolutionary relationships was not seriously taken into account by geneticists and evolutionary biologists until late 20th century, when molecular genetics showed that most gene networks responsible for embryonic development and functioning of metazoans were conserved; evolution may have well worked by tinkering and bricolage of a basic genetic toolkit to shape animal body plans and adaptations.

In Comparative Zoology, Evolution and modern Evolutionary Developmental Biology (Evo-Devo), the origin of vertebrates has always received much attention, most probably due to a vertebroand anthropo-centrist view of scientists (Duboule, 2007), but also due to the fact that the origin of vertebrates involved the appearance of several intriguing innovations. Among those, vertebrae, regionalised anterior brain, neural crest cells and paired limbs evolved in the ancestor of vertebrates and generated, among other complex vertebrates, ourselves. The nature of this ancestor has been subject of debate, and the position of the clades accompanying vertebrates in the phylum chordates was, until very recently, controversial.

Lancelets, or amphioxus, are small marine animals with a fishlike shape that spend most of their life partially burrowed in the sand, filtering sea water trough their jawless mouth, in search of their main food, unicellular algae. Currently, the subphylum Cephalochordata comprises 29 species of amphioxus (Poss and Boschung, 1996). The brilliant embryologist Alexander Kowalevsky (1867) already noted that amphioxus shared key anatomical features with vertebrates, such as a hollow dorsal nerve tube, an endostyle, a segmented body derived from somites and a postanal tail (Fig. 1). However, amphioxus lacks some vertebrate key characteristics, including migratory neural crest cells, an endoskeleton, a highly regionalised brain, or paired sense organs (Shimeld and Holland, 2000). Fossil chordates with similar morphology to modern amphioxus have been described (Chen et al., 1999),

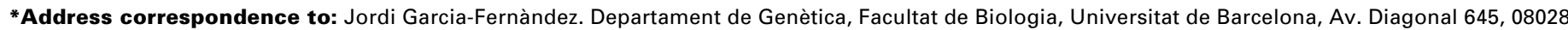
Barcelona, Spain. Fax: +34-93-403-4420. e-mail: jordigarcia@ub.edu

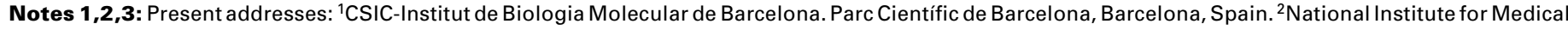
Research, Mill Hill, London, UK. ${ }^{3}$ CDGM/IDIBELL, Hospital Duran i Reynals, L'Hospitalet, Spain.
}

Final author-corrected PDF published online: 10th June 2008

ISSN: Online 1696-3547, Print 0214-6282

(C) 2008 UBC Press

Printed in Spain 


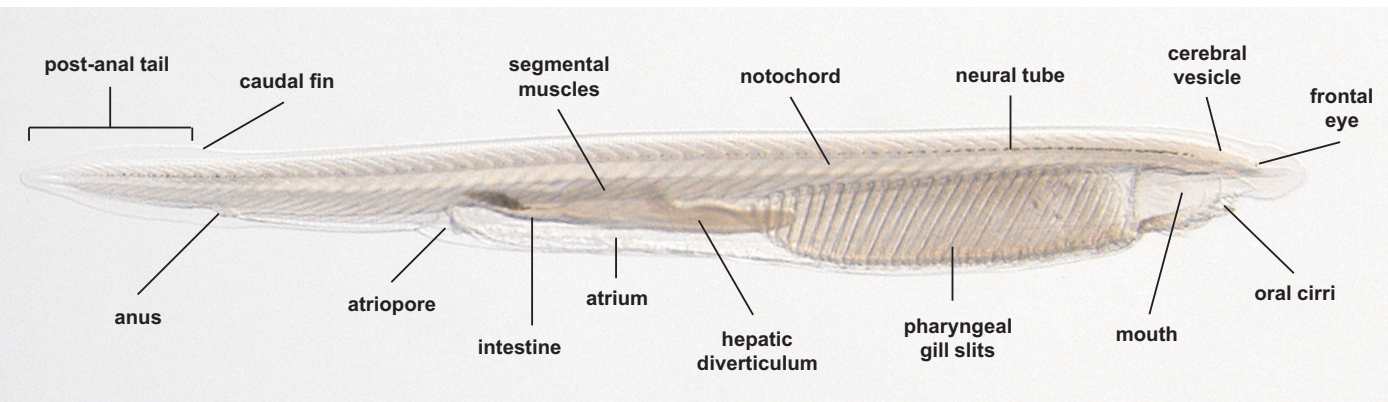

Fig. 1. Amphioxus body plan. Labels indicate the main anatomical characters in a juvenile of the European amphioxus B. lanceolatum. Anterior is to the right.

indicating that amphioxus represents, morphologically, a close living proxy of an early chordate. Recent molecular data indicate that not only its body plan but also its genome is the best representative of the ancestral chordate genome, and perhaps one of the best approaches so far to the ancestral «complex Urbilateria» (Baguñà and Riutort, 2004).

\section{The changing (and definitive?) phylogenetic position of amphioxus: implications for the ancestral chordate and the invertebrate/vertebrate transition}

Although amphioxus was originally described as a mollusc (Pallas, 1774), during the late 19th century it became clear that either cephalochordates or urochordates (ascidians) were the most basal chordates (Kowalevsky, 1867). The prevalent view on the origin of chordates during the 20th century was that urochordates represented the most basal branch of chordates (Fig. 2A). In this scenario, the chordate (and deuterostome) ancestor was probably a sessile animal similar to the ascidian adult that would have given rise to the ancestor of amphioxus and vertebrates by neoteny (Sly et al., 2003). However, in the last few years, the position of cephalochordates and tunicates has been reversed. By analysing a large amount of molecular data, Delsuc and colleagues (Delsuc et al., 2006) found that cephalochordates branched earlier than it was thought, representing the sister group of a urochordatevertebrate clade (Fig. 2B). This change in the chordate phylogeny has profound implications for the understanding of the evolution of body plans. First, it suggests that the ancestral chordate (and perhaps the ancestral deuterostome) was a free-living, worm or fish-like shaped organism, with a series of pharyngeal gill slits. Second, it implies that the origin of vertebrates may have not occurred by neoteny of a urochordate-like sessile animal. Finally, it indicates that urochordates and echinoderms have a derived body plan, whereas amphioxus and vertebrates may have retained body plans more comparable to the ancestral deuterostome.

That amphioxus is the best representative of the first chordate has insightful implications, which help to clarify the evolutionary pathways within chordates and to vertebrates. Two examples are the origin of the Spemann-Mangold organizer, and the origin of the neural crest. The discovery of the former (Spemann and Mangold, 1924), a small group of cells in the early gastrula with inductive properties that establish the vertebrate body plan, was a landmark in experimental embryology. However, the evolu-

tionary origin of the organizer itself was obscured until the reversal of the positioning of cephalochordates and urochordates, and the publication of recent molecular data. First, although the ascidian larva is vertebrate-like in shape, its embryonic development is deployed neither with the presence of an organizer-like territory, nor by large inductive mechanisms (Kourakis and Smith, 2005). Second, pioneering work in experimental embryology in China in the 1960s suggested that the dorsal part of the amphioxus blastopore is homologous to the vertebrate organizer, having similar inductive properties (Tung et al., 1962). Finally, Yu and colleagues recently reported that, at the molecular level, the amphioxus gastrula may have such an inductive territory with separate signalling centers to pattern the Antero-Posterior and Dorso-Ventral embryonic axis very similar to vertebrates (Yu et al., 2007). Altogether, these data clarify the origin of the organizer: it appeared, at least, in the chordate ancestor, and therefore is not a vertebrate novelty, but it was secondarily lost in urochordates, maybe as an adaptation to their small size and rapid and regulative development (Garcia-Fernàndez et al., 2007).

Neural crest cells have a major impact in vertebrate development. They differentiate into a vast array of cell types, generating a wide variety of tissues and organs, such as craniofacial skeleton, spinal ganglia, parasympathetic and sympathetic nervous systems and teeth (Hall, 1999; Trainor et al., 2003). Although most components of the gene networks involved in neural crest specification are expressed in the border of the amphioxus neural tube, in a similar pattern to vertebrates, no cell migration has been reported in amphioxus at these embryonic stages and locations (Barrallo-Gimeno and Nieto, 2006; Meulemans and Bronner-Fraser, 2004). Intriguingly, a population of cells in the amphioxus neurula shows migratory capabilities and may have the ability to perform epithelial/mesenchymal transition (Benito-Gutiérrez et al., 2005), but they are not located near the dorsal neural tube. On the other

A

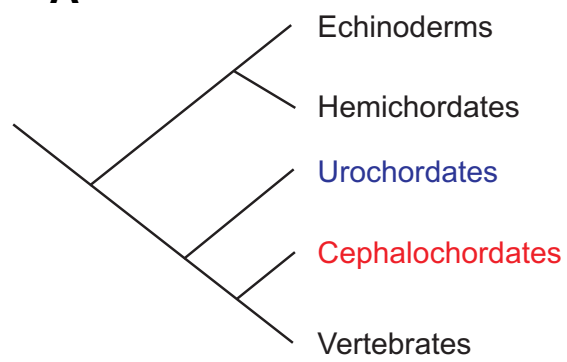

Fig. 2. Deuterostome phylogeny, old and new views. (A) Classical phylogeny: cephalochordates are the sister group of vertebrates, and urochordates are the basal chordates. (B) Present phylogeny: cephalochordates diverged before the urochordate-vertebrate split.

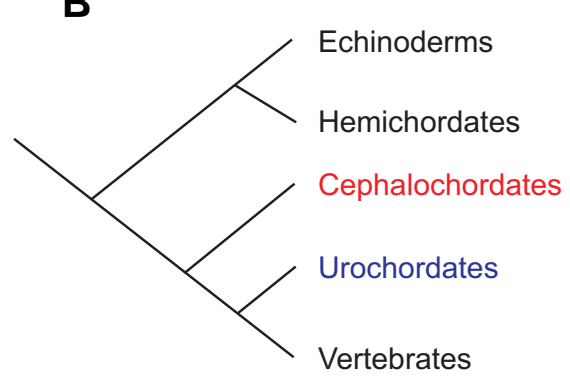



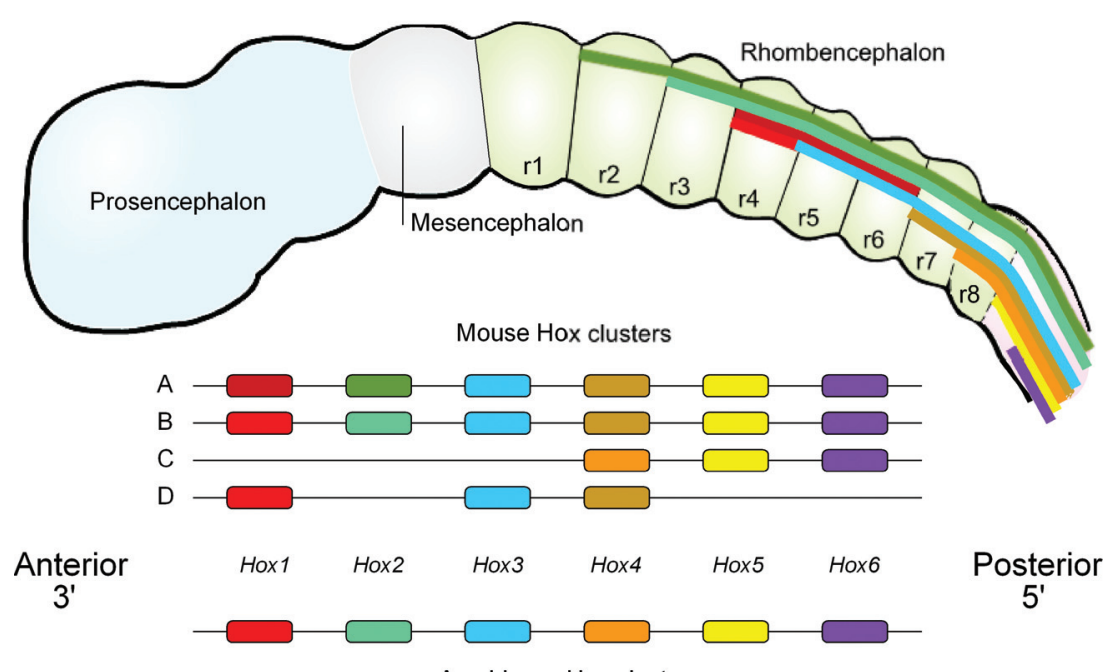

Amphioxus Hox cluster

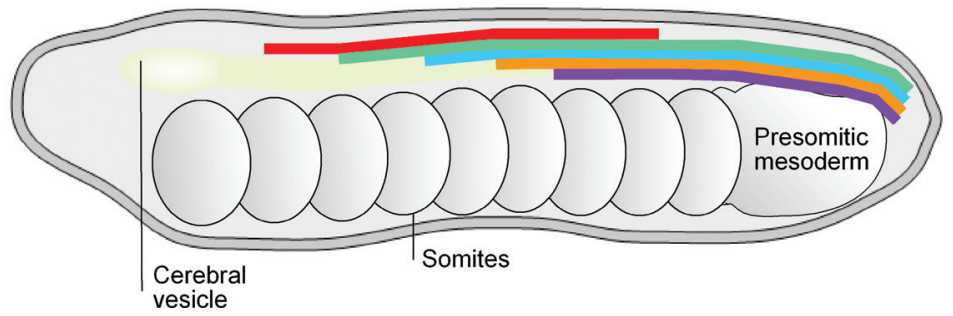

Fig. 3. Colinear expression of Hox genes in the Central Nervous System of vertebrates and amphioxus. Hox genes are expressed in a spatial collinear manner in the hindbrain of vertebrates (top), generating a 'Hox code' (Kessel and Gruss, 1991) that will direct the fate of the neural crest cells. In amphioxus (bottom), spatial collinearity in the Central Nervous System is also observed (Schubert et al., 2006; Wada et al., 1999).

hand, a cell population in the ascidian urochordate Ecteinascidia turbinatabehaves, at least partially, as canonical neural crest cells (Jeffery et al., 2004). Even if all these data are taken with caution, the evolutionary path to the origin of genuine neural crest cells seems clearer: between cephalochordates and vertebrates, some cells adjacent to the neural tube acquired migratory capabilities, and bona fide neural crest cells evolved later, along the lineage leading to vertebrates.

\section{A genome to dream of...}

A statement in a classic Biology textbook from the 1960s well represents the importance of the lancelet in understanding vertebrate origins: "If amphioxus had not been discovered, it would have to have been invented" (Grove and Newell, 1961). The authors refer to the prototypical condition of the amphioxus embryo and body plan; they are as one would have expected of the ancestor of vertebrates.

Molecular genetics in amphioxus started in 1992, with the cloning of the first homeobox gene, AmphiHox3, equally related to the three human Hox3 genes (Holland et al., 1992). This early finding was partly in agreement with the early ideas of Susumu Ohno, who anticipated that during vertebrate evolution, one or several genome duplications took place (Ohno, 1970). Ohno nicely linked those genome duplication events to the concept of neofunctionalisation of duplicated genes that would be the raw material for further innovations without the constraints of strong purifying selection. Although gene co-option through changes in cis-regulatory sequences has overtaken gene duplication as the main player in our understanding of evolution (Carroll, 2005), the main question of whether vertebrates are octoploids or not has been on hot debate in many forums (e.g. (Furlong and Holland, 2002)). The full sequencing of the human genome prompted their authors to propose that the amphioxus genome would give the answer to such a question (Consortium, 2001). After the analyses of the urochordate Ciona intestinalis genome (Dehal et al., 2002) the first global analysis of the amphioxus genome will soon unravel the details of Ohno's hypotheses.

Nonetheless, previous analyses of individual genes, gene networks and gene clusters have already indicated that, as a general rule, amphioxus has single members for nearly all vertebrate gene families (Holland et al., 2004). Paradigmatic examples are the Hox cluster (Garcia-Fernàndez, 2005b) and its evolutionary sister, the ParaHox cluster (Brooke et al., 1998). Mammals have four Hox clusters with a representation of 13 paralogous groups. None of these clusters has more than 11 of these paralogous groups, whereas amphioxus has a single Hox cluster, with one member of each paralagous group, in the single, and at the same time, richest, Hox cluster so far described. Moreover, amphioxus contains a $14^{\text {th }}$ Hox gene, AmphiHox14 (Ferrier et al., 2000). This finding was initially puzzling, until a $14^{\text {th }}$ Hox gene was found in coelacanth and shark (Powers and Amemiya, 2004): AmphiHox14 did not represent an amphioxus oddity; instead, Hox 14 was lost in the lineage to tetrapods (Garcia-Fernàndez, 2005a). Intriguingly, amphioxus also possesses a Hox 15 gene (Holland et al., 2008)

Interestingly, the expression of Hox genes in amphioxus also exemplifies the use of amphioxus developmental genes as tracers of hidden homology. The amphioxus neural tube has no evident morphological segmented boundaries, like rhombomeres. However, Hox genes are expressed in a staggered collinear manner, with nested expression (Fig. 3). This is reminiscent to the rhombomere nested phase in which the same paralogous Hox genes are expressed in the vertebrate hindbrain. Although inferring homology through gene expression comparison may not reflect always true morphological homology, these similarities strongly suggest that a large region of the amphioxus nerve cord is equivalent to the vertebrate rhombencephalon, and that the highly developed forebrain of vertebrates evolved from a small region of the anterior neural tube of the chordate ancestor, which in amphioxus is represented by the frontal cerebral vesicle ( $\mathrm{Hol}-$ land and Takahashi, 2005; Lacalli, 2006).

\section{...but also a modern genome}

Although the amphioxus genome seems close to the prototypical chordate genome, it is not a genome that froze in an ancestral state, without change. Amphioxus may be in morphological stasis 
and its genome might have not experienced high overall evolutionary turnovers, like in other derived lineages (Consortium, 1998; Dehal et al., 2002). Nevertheless, after 500 Million Years (MYs) of lineage-specific evolution from the ancestor of chordates, some amphioxus-specific footprints are present, even though they have not distorted the morphology or the basic set of genes and gene networks.

We found one of these footprints while studying somitogenesis, analysing whether or not the cycling mechanism operating in vertebrates is ancestral to chordates (Pourquié, 2003). Somites are an evolutionary innovation that appeared at the origin of chordates. Amphioxus possesses epithelial axial somites without differentiation into sclerotome and dermamyotome (Pourquie, 2001). Unexpectedly, not one but eight basic helix-loop-helix genes of the hairy family were found (Minguillón et al., 2003). The expression patterns of four of those genes in amphioxus were striking: they were expressed in non-overlapping domains in the embryo, including somites, nerve cord and gut (Fig. 4B). A careful analysis of these expression patterns showed that the summation of all the patterns represents the expression of the single mouse hairy gene. These results suggest that AmphiHairy genes have undergone a process of sub-functionalisation due to gene duplication, in agreement with the DDC model (duplication/degeneration/complementation) proposed by Force and colleagues (Force et al., 1999). According to this model, after gene duplication of a complex regulatory region, some of the enhancers are differentially maintained or lost among the newly created duplicates. Therefore, in order to ensure the complex, multiple expression pattern of the ancestral, single gene, none of the duplicated copies can be lost by non-functionalisation (degeneration). Developmental genes, which often have very complex regulatory regions, are more prone to undergo sub-functionalisation. This may well be the reason why they have had a much lower rate of loss in vertebrate genomes, after polyploidisation, than house-

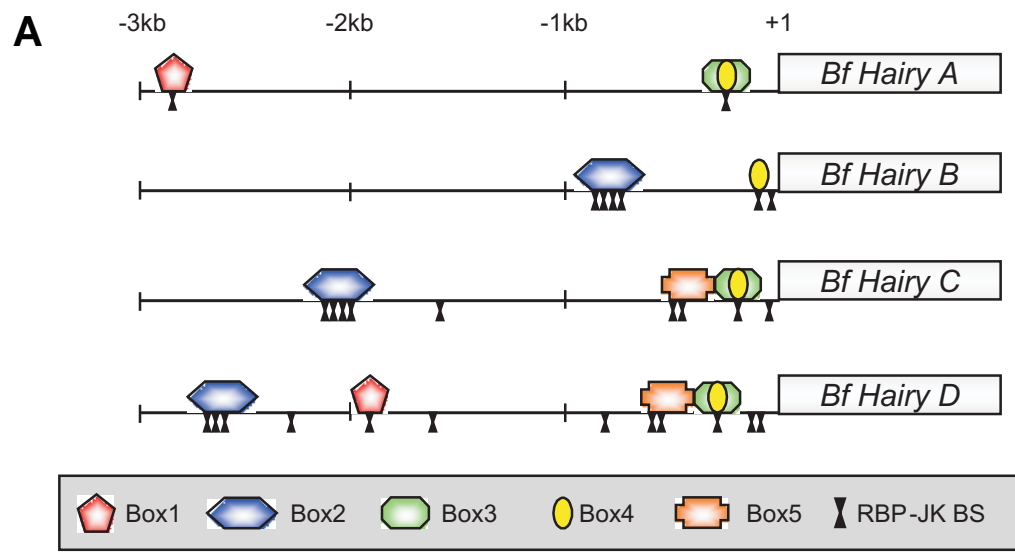

B

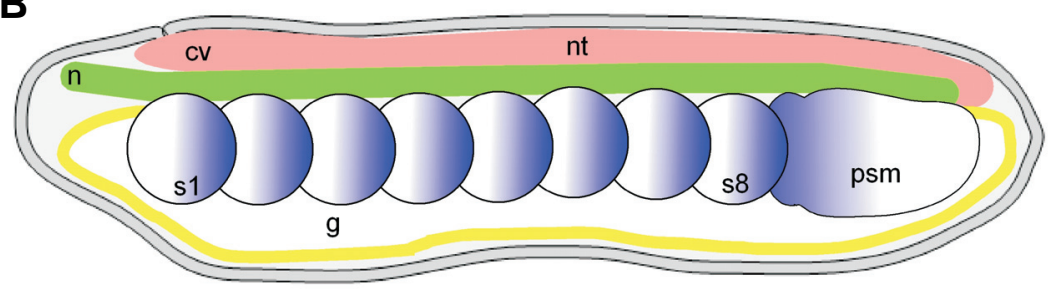

keeping or constitutive genes. We further investigated the subfunctionalisation process of the amphioxus hairy genes, by analysing the 5' regulatory regions of AmphiHairy $A$ - $D$ (JiménezDelgado et al., 2006). As expected, several conserved regions were detected among some duplicates (Fig. 4A).

Hence, although amphioxus shows high constraints in its genome, it is a contemporary genome, with remnants of particular duplications and expansions. The complete analysis of the lancelet genome will bring to light other cases apart from those already reported (Minguillón et al., 2002); this analysis may also help to understand genome dynamics in an almost unique case in which everything necessary to conserve the basic chordate body plan has been retained; as examples, consider the recurrent clustering of Iroquois genes (Irimia et al., 2008) or the expansion of the tyrosine kinase family (D'Aniello et al., 2008).

\section{The embryo: from Tampa Bay to Banyuls sur mer}

It is a classic recipe: a genomic and developmental animal model system must have a model genome (as amphioxus has), a model embryo (which it also has), and these embryos should be easy to obtain. Until recently, the friendly lancelet did not fit this recipe. The first experimental studies on amphioxus embryology, during the 19th and 20th centuries, were carried out on embryos caught in the wild and under difficult conditions. Three main species are currently being studied: the American, Branchiostoma floridae, found in the shallow waters of Tampa Bay (Holland and Yu, 2004), the Asian, B. belcheri(Zhang et al., 2007), and the European, B. lanceolatum (Fuentes et al., 2004). Most developmental genetics studies have been performed on $B$. floridae, and the genome sequenced is also that from $B$. floridae. The study of embryos of $B$. floridae has been possible in recent years thanks to the hard work of Nick and Linda Holland (Scripps Institution of Oceanography, San Diego, USA). In July-August every year, up to a dozen amphioxus researchers were kindly hosted by Nick, Linda, and John Lawrence, from the University of South Florida. The main aim was to obtain $B$. floridae embryos. And this was not trivial. Populations of $B$. floridae, as most species of amphioxus, spawn synchronously in the wild, at sunset of very few days a year (Holland and Yu, 2004; Stokes and Holland, 1996). This means that experimentation with live

Fig. 4. Schematic representation of correlation between putative conserved sequence elements and Hairy expression territory. (A) Schematic representation of the 5' region of amphioxus HairyA, B, C and D genes showing conserved non-coding regions. Five different conserved elements were identified and are shown in different colours. Box2 (b/ue) would correlate with the expression of HairyB, HairyC, HairyD in somites (s) and presomitic mesoderm (psm). Box3 (green) with HairyC and HairyD in notocord (n). Box4 (yellow) with the expression of HairyA, HairyC and HairyD in gut endoderm. Box5 (pink) with the expression of all four genes in neural tube $(n t)$. Positions of the antero (A)-posterior (P) and dorso (D)ventral (V) axes are indicated. (B) Schematic representation of a lateral view of an amphioxus neurula showing the composite expression of AmphiHairy A to D. Antero (A)posterior (P) and dorso (D)-ventral (V) axes are indicated. 
embryos was a limiting factor for experimental research. As such, little literature includes gene or embryo manipulation (Beaster-Jones et al., 2007; Benito-Gutiérrez et al., 2005; Schubert et al., 2005).

Hatschek, Conklin or Kowalevsky, among other classic embryologists, studied the European species, $B$. lanceolatum, (Conklin, 1932; Hatschek, 1881; Kowalevsky, 1867) obtained in several research marine stations around Europe. But European molecular geneticists interested in the invertebrate/vertebrate transition, either concentrated in echinoderms or urochordates, much more amenable to experimentation, or the few still in love with amphioxus followed the path to the Florida lancelet ev-
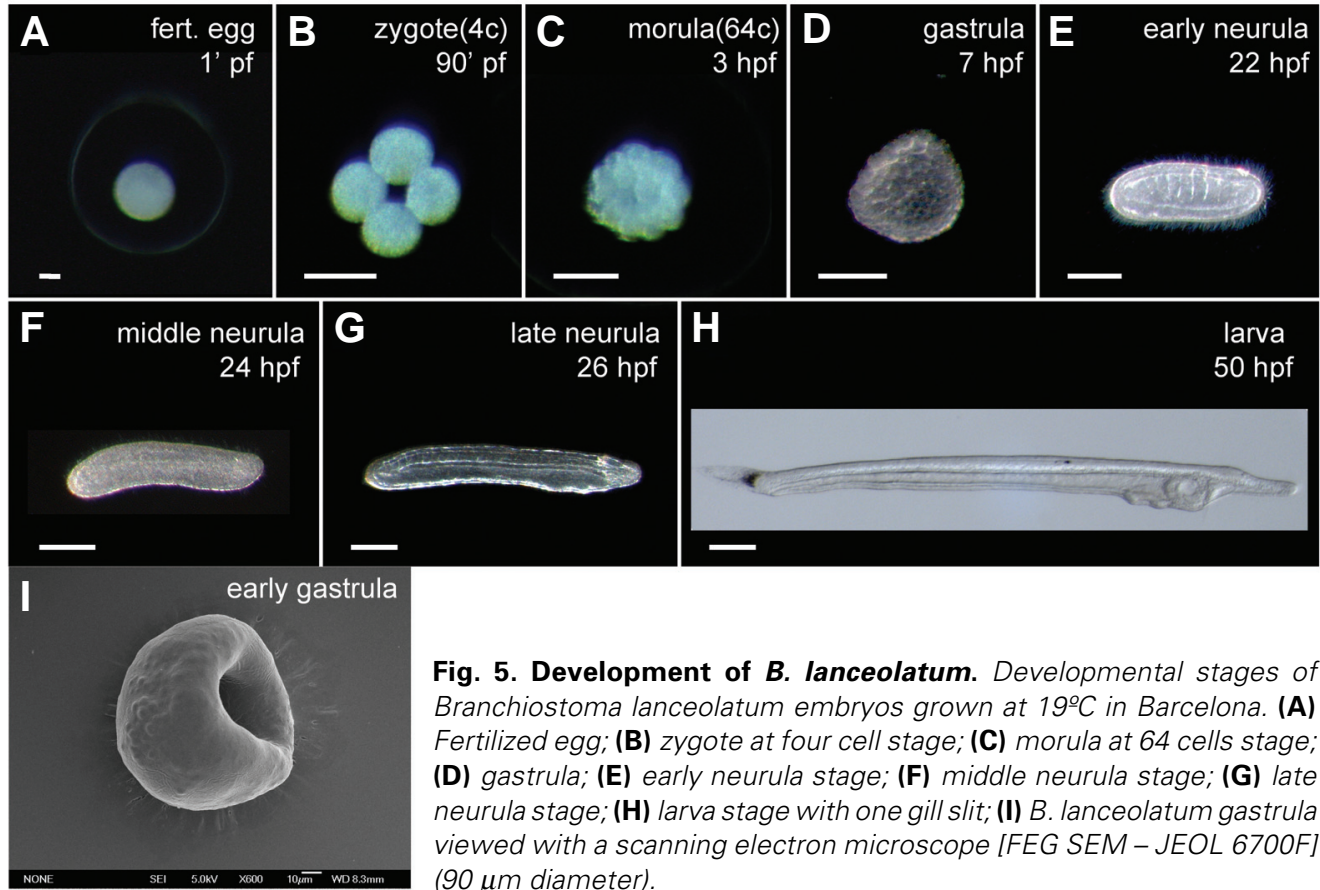

late neurula

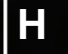
ery summer. Few years ago, however, a European initiative, leaded by French groups, and including Spanish, Italian and German labs, started an ambitious collaboration to study the natural reproduction of $B$. lanceolatumin the beaches near the Laboratory Arago, BanyulsSur-Mer, France. This initiative ended with major success: we were not only able to obtain embryos in the lab coincidently to the natural spawning nights in the field (April to June), but also developed a technique to make the animals spawn in the lab independently of field conditions (Fuentes et al., 2007; Fuentes et al., 2004). In practice, this means that amphioxus embryos can be obtained in Banyuls on demand, during the spawning season. And this, of course, opens the door to develop amphioxus as a fully experimental model system. Here we present an illustrated development table of $B$. lanceolatum, from fertilization to larval stages (Fig. $5 \mathrm{~A}-\mathrm{H}$ ), and scanning microscope pictures of gastrula stage (Fig. 5I).

The available amphioxus genome is that of $B$. floridae,
$26 \mathrm{hpf}$

$50 \mathrm{hpf}$
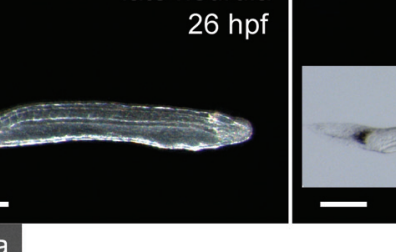

Fig. 5. Development of B. lanceolatum. Developmental stages of Branchiostoma lanceolatum embryos grown at $19^{\circ} \mathrm{C}$ in Barcelona. (A) Fertilized egg; (B) zygote at four cell stage; (C) morula at 64 cells stage; (D) gastrula; (E) early neurula stage; (F) middle neurula stage; (G) late neurula stage; (H) larva stage with one gill slit; (I) B. lanceolatum gastrula viewed with a scanning electron microscope [FEG SEM - JEOL 6700F] (90 $\mu \mathrm{m}$ diameter).

whereas it is now easier to obtain $B$. lanceolatum embryos, and $B$. belchieri research is growing in China and Japan (Wang et al., 2005; Zhang et al., 2007). A list of genomic and experimental tools of each species is shown in Table 1. Thus not only one, but three species of amphioxus will serve, in addition, to reveal, towards phylogenetic footprinting, conserved gene regulatory regions to show up those functional elements in the grounds of modern comparative and functional genomes.

\section{The Barcelona lab: genome and embryos a la carte}

The amphioxus research in Barcelona started when JGF, inspired by his post-doctoral experience with Peter Holland in Oxford (Garcia-Fernàndez and Holland, 1994; Holland et al., 1994), was lucky to be joined by a group of scientists whose main interest was Evo-Devo at the chordate/vertebrate origin, using amphioxus as a model organism. We initially mainly

TABLE 1

\section{GENOMIC RESOURCES AND EMBRYO AVAILABILITY FOR THE THREE MAINLY USED BRANCHIOSTOMA SPECIES}

\begin{tabular}{|c|c|c|c|}
\hline & B. lanceolatum & B. floridae & B. belcheri \\
\hline $\begin{array}{l}\text { Whole genome } \\
\text { sequence }\end{array}$ & - & $\begin{array}{l}\text { Joint Genome Institute } \\
\text { (http://genome.jgi-psf.org//Brafl1/Brafl1.home.html) }\end{array}$ & - \\
\hline ESTs & - & 277538 in Genbank & 538 in Genbank \\
\hline BAC library & in process & Children's Hospital Oakland Research Institute http://bacpac.chori.org & Wang et al. 2005 \\
\hline $\begin{array}{l}\text { Phage Genomic DNA } \\
\text { library }\end{array}$ & Cañestro et al., 2000 & Garcia-Fernàndez and Holland (1994) & \\
\hline cDNA library & From posterior part of adult (Sato et al., 2003) & $\begin{array}{l}\text { From egg, gastrula, neurula, larvae and adult } \\
\text { http://dolphin.lab.nig.ac.jp/bball.html }\end{array}$ & $\begin{array}{l}\text { From adult gut (Luan et al., 2007), } \\
\text { notochord (Suzuki and Satoh, 2000), } \\
\text { neural embryonic tissue (Dong et al. } \\
\text { 2005), neurula (Mou et al., 2002, Lin et } \\
\text { al., 2004) }\end{array}$ \\
\hline \multicolumn{4}{|l|}{ Embryos availability } \\
\hline Natural spawning & $\begin{array}{l}\text { Multiple spawnings, synchronous or not during } \\
\text { the spawning season (from April to June) }\end{array}$ & $\begin{array}{l}\text { Multiple synchronous spawnings with } 1-2 \text { weeks intervals during the } \\
\text { spawning season }\end{array}$ & Few contigous days per year \\
\hline Induced spawning & $\begin{array}{l}\text { Heat-schock every day during the spawning } \\
\text { season. Day/night cycle controlled }\end{array}$ & Electric pulse the days of spawning in the field & No artificial induction \\
\hline
\end{tabular}



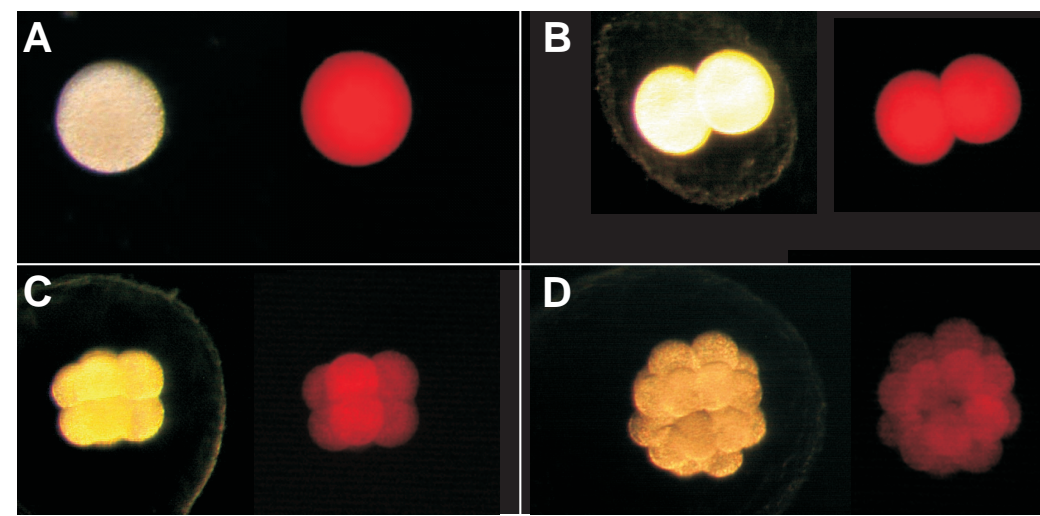

Fig. 6. Injection in Branchiostoma lanceolatum eggs. Soon after injection, eggs were fertilized with fresh sperm, and then washed and the development followed at $19^{\circ} \mathrm{C}$. By the use of a fluorescent dye (Texas Red, $5 \mathrm{mg} / \mathrm{ml}$ ) it was possible to discriminate the injected eggs from the uninjected. In each panel, the fluorescent picture is on the right side, and light image on the left. (A) One cell stage (egg) before fertilization, (B) two cell stage embryo, (C) eight cell stage embryo and (D) 32 cell stage embryo.

focused on amphioxus homeobox genes (Brooke et al., 1998; Ferrier et al., 2000; Minguillón and Garcia-Fernàndez, 2002) and the data obtained in our laboratory served to suggest global hypothesis on the evolution of homeobox clusters in metazoans (Garcia-Fernàndez, 2005a; Garcia-Fernàndez, 2005b; Minguillón and Garcia-Fernàndez, 2003). Later we expanded as well the research to more global studies: the evolution of nervous system and mesodermal derivatives, genome evolution, alternative splicing and phylogenies are among interests in the recent years (e.g. Benito-Gutiérrez et al., 2006; Irimia et al., 2007a; Irimia et al., 2007b; Irimia et al., 2007c; Irimia et al., 2007d).

As an example, recent work on the free amino acid composition of the $B$. lanceolatum nerve cord has shown that amphioxus contains intermediate amounts of these amino acids compared to invertebrates and vertebrates. This represents a new and promising research line that could give insights into the evolution of neurotransmission, since some of them, such as DAspartic acid (D-Asp, the D form of L-Aspartate) and NMDA (the methylated form of D-Asp) among others, are implicated in neuronal and hormonal activity (D'Aniello et al., 2007; D'Aniello and Garcia-Fernàndez, 2007; Pascual-Anaya and D'Aniello, 2006).

Notwithstanding, the main goal of our team is to develop the amphioxus as an ambitious model system for Experimental Evo-Devo. For instance, our dream is to induce in amphioxus experimental genetic changes that would be predicted to have caused a major evolutionary change, e.g, the origin of paired fins/limbs, neural crest or a highly developed brain. The bases are there: a genome project (B. floridae), genomic tools for phylogenetic footprinting (molecular data from $B$. lanceolatum), and close access to embryos in Banyuls sur mer.

As a first step, we managed to establish a long-term culture facility for amphioxus in a "dry lab" (not a marine station). To our knowledge, Barcelona hosts the only dry lab where amphioxus are maintained, and spawning is induced under controlled conditions. Spawning is induced not only the day but also at the time that the researcher wishes: no longer at the sunset, with long nights of work ahead, but at noon, after succeeding in inverting the day/night cycle of the amphioxus cultures (Fuentes et al., 2007).

\section{The wishes, the prospects, the future}

We anticipate that amphioxus research will grow and give interesting new surprises to developmental and evolutionary biologists. The research community is increasing and the imminent publication of a draft of the amphioxus genome may be a breakthrough. The friendly little anchovy fillet, peacefully lying on the sand, may become nervous in our fish tanks, at the doors of the experimental genetics era, thanks to the collaborative efforts of researchers world-wide. A country song by the marine biologist Phylip Pope concerning amphioxus became a favourite at the summer courses of Cold Spring Harbour Laboratories; the chorus can be found elsewhere (Garcia-Fernàndez, 2006): It's a long way from Amphioxus. It is a long way to us. Experimental Evo-Devo in amphioxus is a long way, it is a long way for us, but an amazingly exciting one. Having amphioxus eggs injected and developed, is a nice milestone on the way. Here we show, for the first time and to set up manipulation systems in this species, fluorescent $B$. lanceolatumembryos (Fig. 6), born on demand and injected in our resources, the AmphiBCN lab.

\section{Acknowledgements}

We wish to thank Peter Holland, Linda Holland, Nick Holland, Seb Shimeld, David Ferrier, Joan Comella and Angela Nieto for long-lasting collaboration and friendship; Hector Escrivà and the director of the Oceanographic Institute of Banyuls for such great enterprise; Jaume Baguñà, Emili Saló, Roser González-Duarte, Ricard Albalat and Gemma Marfany for helpful discussions and help; Jon Giblin for cheking the manuscript and Agnes Boutet for captions D and E of Fig. 5. The authors also thank Franco and Gennaro lamunno of Stazione Zoologica "A. Dohrn" (Napoli, Italy) for their technical support with electron microscopy. JGF also thanks Laura for flamboyantly inspiring him. The lab research is supported by grant BFU2005-00252 from the Ministerio de Educación y Ciencia, Spain. SDA holds a "Juan de la Cierva" postdoctoral contract of the Ministerio de Educación y Ciencia, Spain, and SB holds an EMBO postdoctoral L T fellowship. SJD and MI hold FPI fellowships, and IM FPU fellowships (MEC, Spain) and JPA a CIRIT fellowship (Generalitat de Catalunya).

\section{References}

BAGUÑÀ, J. and RIUTORT, M. (2004). The dawn of bilaterian animals: the case of acoelomorph flatworms. BioEssays 26: 1046-1057.

BARRALLO-GIMENO, A. and NIETO, M.A. (2006). Evolution of the neural crest Adv. Exp. Med. Biol. 589: 235-44.

BEASTER-JONES, L., SCHUBERT, M. and HOLLAND, L.Z. (2007). Cis-regulation of the amphioxus engrailed gene: Insights into evolution of a muscle-specific enhancer. Mech Dev124: 532-42.

BENITO-GUTIÉRREZ, È., GARCIA-FERNÀNDEZ, J. and COMELLA, J.X. (2006). Origin and evolution of the Trk family of neurotrophic receptors. $\mathrm{Mol} \mathrm{Ce} / \mathrm{l}$ Neurosci31: 179-92.

BENITO-GUTIÉRREZ, E., NAKE, C., LLOVERA, M., COMELLA, J.X. and GARCIAFERNÀNDEZ, J. (2005). The single AmphiTrk receptor highlights increased complexity of neurotrophin signalling in vertebrates and suggests an early role in developing sensory neuroepidermal cells. Development 132: 2191-202. 
BROOKE, N.M., GARCIA-FERNÀNDEZ, J. and HOLLAND, P.W.H. (1998). The ParaHox gene cluster is an evolutionary sister of the Hox gene cluster. Nature 392: 920-2.

CANESTRO, C., HJELMQVIST, L., ALBALAT, R., GARCIA-FERNÀNDEZ, J., GONZALEZ-DUARTE, R. and JORNVALL, H. (2000). Amphioxus alcohol dehydrogenase is a class 3 form of single type and of structural conservation but with unique developmental expression. European Journal of Biochemistry267: 6511-6518.

CARROLL, S.B. (2005). Evolution at two levels: on genes and form. PLOS Bio/3: e245.

CONKLIN, E. (1932). The embryology of Amphioxus. J Morph 54: 69-151.

CONSORTIUM, I.H.G.S. (2001). Initial sequencing and analysis of the human genome. Nature 409: 860-921.

CONSORTIUM, T.C.E.S. (1998). Genome sequence of the nematode $C$. elegans. a platform for investigating biology. Science 282: 2012-2018.

CHEN, J.-Y., HUANG, D.-Y. and LI, C.-W. (1999). An early Cambrian craniate-like chordate. Nature 402: 518-522.

D'ANIELlO, S., FISHER, G.H., TOPO, E., FERRANDINO, G., GARCIAFERNÀNDEZ, J. and D'ANIELLO, A. (2007). N-Methyl-D-aspartic Acid (NMDA) in the nervous system of the amphioxus Branchiostoma lanceolatum. BMC Neuroscience In press.

D'ANIELLO, S. and GARCIA-FERNÀNDEZ, J. (2007). D-aspartic acid and L-amino acids in the neural system of the amphioxus Branchiostoma lanceolatum. Amino Acids 32: 21-6.

D'ANIELLO, S., IRIMIA, M., MAESO, I., PASCUAL-ANAYA, J., JIMÉNEZ-DELGADO, S., BERTRAND, S. and GARCIA-FERNÀNDEZ, J. (2008). Gene expansion and retention leads to a diverse Tyrosine kinase superfamily in amphioxus. Mol Biol Evol(in press)

DARWIN, C. (1859). On the Origin of Species. John Murray, London, UK

DEHAL, P., SATOU, Y., CAMPBELL, R.K., CHAPMAN, J., DEGNAN, B., DE TOMASO, A., DAVIDSON, B., DI GREGORIO, A., GELPKE, M., GOODSTEIN, D.M. et al. (2002). The draft genome of Ciona intestinalis: insights into chordate and certebrate origins. Science 298: 2157-2167.

DELSUC, F., BRINKMANN, H., CHOURROUT, D. and PHILIPPE, H. (2006). Tunicates and not cephalochordates are the closest living relatives of vertebrates. Nature 439: 965-968

DONG, M., FU, Y., YU, C., SU, J., HUANG, S., WU, X., WEI, J., YUAN, S., SHEN, $Y$. and $X U$, A. (2005). Identification and characterisation of a homolog of an activation gene for the recombination activating gene 1 (RAG 1) in amphioxus. Fish Shellfish Immunology 19: 165-174.

DUBOULE, D. (2007). The rise and fall of Hox gene clusters. Development 134: 2549-2560.

FERRIER, D.E.K., MINGUILLÓN, C., HOLLAND, P.W.H. and GARCIAFERNÀNDEZ, J. (2000). The amphioxus Hox cluster: deuterostome posterior flexibility and Hox14. Evol Dev2: 284-93.

FORCE, A., LYNCH, M., PICKETT, F.B., AMORES, A., YAN, Y.L. and POSTLETHWAIT, J. (1999). Preservation of duplicate genes by complementary, degenerative mutations. Genetics 151: 1531-45.

FUENTES, M., BENITO, È., BERTRAND, S., PARIS, M., MIGNARDOT, A., GODOY, L., JIMENEZ-DELGADO, S., OLIVERI, D., CANDIANI, S., HIRSINGER, E. et al. (2007). Insights into spawning behavior and development of the european amphioxus (Branchiostoma lanceolatum). Journal of Experimental Zoology Part B: Molecular and Developmental Evolution 308B: 484-493.

FUENTES, M., SCHUBERT, M., DALFO, D., CANDIANI, S., BENITO, E., GARDENYES, J., GODOY, L., MORET, F., ILLAS, M., PATTEN, I. et al. (2004). Preliminary observations on the spawning conditions of the European amphioxus (Branchiostoma lanceolatum) in captivity. Journal of Experimental Zoology Part B: Molecular and Developmental Evolution 302B: 384-391.

FURLONG, R.F. and HOLLAND, P.W.H. (2002). Were vertebrates octoploid? Philos Trans R Soc Lond B Biol Sci357: 531-44.

GARCIA-FERNÀNDEZ, J. (2005a). The genesis and evolution of homeobox gene clusters. Nat Rev Genet 6: 881-92.

GARCIA-FERNÀNDEZ, J. (2005b). Hox, ParaHox, ProtoHox: facts and guesses. Heredity 94: 145-52.

GARCIA-FERNÀNDEZ, J. (2006). Amphioxus: a peaceful anchovy fillet to illumi- nate chordate evolution (I). Int. J. Biol. Sci. 2: 30-31.

GARCIA-FERNÀNDEZ, J., D'ANIELLO, S. and ESCRIVÀ, H. (2007). Organizing chordates with an organizer. BioEssays 29: 619-624

GARCIA-FERNÀNDEZ, J. and HOLLAND, P.W.H. (1994). Archetypal organization of the amphioxus Hox gene cluster. Nature 370: 563-6.

GROVE, A.J. and NEWELL, G.E. (1961). Animal Biology London.

HALL, B.K. (1999). The Neural Crest in Development and Evolution. Springer, New York.

HATSCHEK, B. (1881). Studien über die entwicklung des Amphioxus. Arb Zool Inst Univ Wien 4: 1-88

HOLLAND, L.Z., LAUDET, V. and SCHUBERT, M. (2004). The chordate amphioxus: an emerging model organism for developmental biology. Cell Mol Life Sci61: 2290-308.

HOLLAND, L.Z. and YU, J.K. (2004). Cephalochordate (amphioxus) embryos: procurement, culture, and basic methods. Methods Cell Bio/74: 195-215.

HOLLAND, P.W. and TAKAHASHI, T. (2005). The evolution of homeobox genes: Implications for the study of brain development. Brain Res Bul/66: 484-90.

HOLLAND, P.W.H., GARCIA-FERNÀNDEZ, J., WILLIAMS, N.A. and SIDOW, A. (1994). Gene duplications and the origins of vertebrate development. Dev. Suppl.125-33.

HOLLAND, P.W.H., HOLLAND, L.Z., WILLIAMS, N.A. and HOLLAND, N.D. (1992) An amphioxus homeobox gene: sequence conservation, spatial expression during development and insights into vertebrate evolution. Development 116 : 653-661.

HOLLAND, L.Z., ALBALAT, R., AZUMI, K, BENITO-GUTIÉRREZ, E., BLOW, M.J., BRONNER-FRASER, M., BRUNET, F., BUTTS, T., CANDIANI, S., DISHAW, L.J., FERRIER, D.E.K., GARCIA-FERNÀNDEZ, J., GIBSON-BROWN, J.J., GISSI, C., GODZIK, A., HALLBOOK, F., HIROSE, D., HOSOMICHI, K., IKUTA T., INOKO, H., KASAHARA, M., KASAMATSU, J., KAWASHIMA, T., KIMURA, A., KOBAYASHI, M., KOZMIK, Z., KUBOKAWA, K., LAUDET, V., LITMAN, G.W., McHARDY, A.C., MEULEMANS, D., NONAKA, M., OLINSKI, R.P., PANCER, Z., PENNACCHIO, L.A., PESTARINO, M., RAST, J.R., RIGOUTSOS, I., ROBINSON-RECHAVI, M., ROCH, G., SAIGA, H., SASAKURA, Y., SATAKE, M., SATOU, Y., SCHUBERT, M., SHERWOOD, N., SHIINA, T., TAKATORI, N., TELLO, J., VOPALENSKY, P., WADA, S., XU, A., YE, Y., YOSHIDA, K., YOSHIZAKI, F., YU, J-K., ZHANG, Q., ZMASEK, C.M., PUTNAM, N.H., ROKHSAR, D.S., SATOH, N. and HOLLAND, P.W.H. (2008) The amphioxus genome illuminates vertebrate origins and cephalochordate biology. Genome Research (In press)

IRIMIA, M., MAESO, I., PENNY, D., GARCIA-FERNÀNDEZ, J. and ROY, S.W. (2007a). Rare Coding Sequence Changes are Consistent with Ecdysozoa, not Coelomata. Mol. Biol. Evol. 24: 1604-7.

IRIMIA, M., PENNY, D. and ROY, S.W. (2007b). Coevolution of genomic intron number and splice sites. Trends Genet 23: 321-325.

IRIMIA, M., RUKOV, J.L., PENNY, D., GARCIA-FERNÀNDEZ, J., VINTHER, J. and ROY, S.W. (2007c). Widespread Evolutionary Conservation of Alternatively Spliced Exons in Caenorhabditis. Mol Biol Evo/25(2): 375-382. (DOI: 10.1093/ molbev/msm262).

IRIMIA, M., RUKOV, J.L., PENNY, D. and ROY, S.W. (2007d). Functional and evolutionary analysis of alternatively spliced genes is consistent with an early eukaryotic origin of alternative splicing. BMC Evol Bio/7: 188.

IRIMIA, M., MAESO, I. and GARCIA-FERNÀNDEZ, J. (2008). Convergent evolution of clustering of Iroquois homeobox genes across metazoans. MolBiol. Evol. (In press; DOI: 10.1093: molbev/msn109).

JEFFERY, W.R., STRICKLER, A.G. and YAMAMOTO, Y. (2004). Migratory neural crest-like cells form body pigmentation in a urochordate embryo. Nature 431: 696-9.

JIMÉNEZ-DELGADO, S., CRESPO, M., PERMANYER, J., GARCIA-FERNÀNDEZ, J. and MANZANARES, M. (2006). Evolutionary genomics of the recently duplicated amphioxus Hairy genes. Int J Biol Sci2: 66-72.

KESSEL, M. and GRUSS, P. (1991). Homeotic transformations of murine vertebrae and concomitant alteration of Hox codes induced by retinoic acid. Ce//67: 89104.

KOURAKIS, M.J. and SMITH, W.C. (2005). Did the first chordates organize without the organizer? Trends in Genetics 21: 506-510.

KOWALEVSKY, A.O. (1867). Entwicklungsgeschichte des Amphioxus lanceolatus 
Mém. Acad. Sci. St. Petersb. 11: 1-17.

LACALLI, T.C. (2006). Prospective protochordate homologs of vertebrate midbrain and $\mathrm{MHB}$, with some thoughts on MHB origins. Int J Bio/ Sci2: 104-9.

LIN, Y., LIANG, K., ZHANG, Y., CHEN, Z. and ZHANG, H. (2004). Genes Expressed in the Amphioxus Notochord Revealed by EST Analysis. Gene Expr Patterns 224: $168-177$.

LUAN, J., LIU, Z., ZHANG, S., LI, H., FAN, C. and LI, L. (2007). Characterization, Evolution and Expression of the Calmodulin1 Genes from the Amphioxus Branchiostoma belcheri tsingtauense. Acta Biochimica et Biophysica Sinica39: 255-264.

MEULEMANS, D. and BRONNER-FRASER, M. (2004). Gene-Regulatory Interactions in Neural Crest Evolution and Development. Dev Cel/7: 291-299.

MINGUILLÓN, C., FERRIER, D.E.K., CEBRIAN, C. and GARCIA-FERNÀNDEZ, J. (2002). Gene duplications in the prototypical cephalochordate amphioxus. Gene 287: 121-8.

MINGUILLÓN, C. and GARCIA-FERNÀNDEZ, J. (2002). The single amphioxus Mox gene: insights into the functional evolution of Mox genes, somites, and the asymmetry of amphioxus somitogenesis. Dev Bio/246: 455-65.

MINGUILLÓN, C. and GARCIA-FERNÀNDEZ, J. (2003). Genesis and evolution of the Evx and Mox genes and the extended Hox and ParaHox gene clusters. Genome Biol. 4: R12.

MINGUILLÓN, C., JIMÉNEZ-DELGADO, S., PANOPOULOU, G., and GARCIAFERNÀNDEZ, J. (2003). The amphioxus Hairy family: diffierential fate after duplication. Development 130: 5903-14.

MOU, C.Y., ZHANG, S.C., LIN, J.H., YANG, W.L., WU, W.Y., WEI, J.W., WU, X.K., DU, J.C., FU, Z.Y., YE, L.T. et al. (2002). EST analysis of mRNAs expressed in neurula of Chinese amphioxus. Biochem Biophys Res Commun 299: 74-84.

OHNO, S. (1970). Evolution by gene duplicationNew York.

PALLAS, P.S. (1774). Naturgeschichte merkwurdiger tiere in welcher vornehmlich neue unbekannte tierarten durch kupferstiche, beschreibungen und erklärungen erläutert werden. Lange, Gottlied A., Berlin Stralsund.

PASCUAL-ANAYA, J. and D'ANIELLO, S. (2006). Free amino acids in the nervous system of the amphioxus Branchiostoma lanceolatum. A comparative study. Int J Biol Sci2: 87-92.

POSS, S.G. and BOSCHUNG, H.T. (1996). Lancelets (Cephalochordata: Branchiostomidae): How many species are valid? Isr J Zoo/42: S13-66.

POURQUIE, O. (2001). Vertebrate somitogenesis. Annu. Rev. Cell Dev. Biol. 17: 311-350.

POURQUIÉ, O. (2003). Vertebrate somitogenesis: a novel paradigm for animal segmentation? Int J Dev Bio/47: 597-603.

POWERS, T.P. and AMEMIYA, C.T. (2004). Evidence for a Hox14 paralog group in vertebrates. Curr Bio/14: R183-4.

SATO, A., MAYER, W.E. and KLEIN, J. (2003). A molecule bearing an immunoglobulin-like $\mathrm{V}$ region of the CTX subfamily in amphioxus. Immunogenetics 55 : 423-7.

SCHUBERT, M., HOLLAND, N.D., LAUDET, V. and HOLLAND, L.Z. (2006). A retinoic acid-Hox hierarchy controls both anterior/posterior patterning and neuronal specification in the developing central nervous system of the cephalochordate amphioxus. Developmental Biology 296: 190-202.

SCHUBERT, M., YU, J.K., HOLLAND, N.D., ESCRIVA, H., LAUDET, V. and HOLLAND, L.Z. (2005). Retinoic acid signaling acts via Hox1 to establish the posterior limit of the pharynx in the chordate amphioxus. Development 132: 6173.

SHIMELD, S.M. and HOLLAND, P.W.H. (2000). Special Feature: Vertebrate innovations. Proc Nat/ Acad Sci US A 97: 4449-4452.

SLY, B.J., SNOKE, M.S. and RAFF, R.A. (2003). Who came first-larvae or adults? origins of bilaterian metazoan larvae. Int. J. Dev. Biol. 47: 623-632.

SPEMANN, H. and MANGOLD, H. (1924). Über Induktion von embryonalanlagen durch implantation artfremder organisatoren. Archiv fürMikroskopische Anatomie und Entwicklungsmechanik 100: 599-638.

STOKES, M.D. and HOLLAND, N.D. (1996). Reproduction of the Florida lancelet (Branchiostoma floridae): spawning patterns and fluctuations in gonad indexes and nutritional reserves. Invertebrate Biology 115: 349-359.

SUZUKI, M.M. and SATOH, N. (2000). Genes Expressed in the Amphioxus Notochord Revealed by EST Analysis. Dev Bio/224: 168-177.

TRAINOR, P.A., MELTON, K.R. and MANZANARES, M. (2003). Origins and plasticity of neural crest cells and their roles in jaw and craniofacial evolution. Int. J. Dev. Biol. 47: 541-553.

TUNG, T.C., WU, S.C. and TUNG, Y.Y.F. (1962). Experimental studies on the neural induction in amphioxus. Scienta Sinica XI: 629-664.

WADA, H., GARCIA-FERNÀNDEZ, J. and HOLLAND, P.W.H. (1999). Colinear and segmental expression of amphioxus Hox genes. Dev Bio/213: 131-41.

WANG, W., XU, H.L., LIN, L.P., SU, B. and WANG, Y.Q. (2005). Construction of a BAC Library for Chinese Amphioxus Branchiostoma belcheri and Identification of Clones Containing Amphi-Pax Genes. Genes Genet Syst 80: 233-6.

YU, J.-K., SATOU, Y., HOLLAND, N.D., SHIN-I, T., KOHARA, Y., SATOH, N., BRONNER-FRASER, M. and HOLLAND, L.Z. (2007). Axial patterning in cephalochordates and the evolution of the organizer. Nature 445: 613-617.

ZHANG, Q.-J., SUN, Y., ZHONG, J., LI, G., LÜ, X.-M. and WANG, Y.-Q. (2007). Continuous culture of two lancelets and production of the second filial generations in the laboratory. Journal of Experimental Zoology Part B: Molecular and Developmental Evolution 308B: 464-472. 


\section{Related, previously published Int. J. Dev. Biol. articles}

See our recent Special Issue Ear Development edited by Fernando Giraldez and Bernd Fritzsch at: http://www.ijdb.ehu.es/web/contents.php?vol=51\&issue=6-7

Peter Holland, homeobox genes and the developmental basis of animal diversity.

Shimeld SM.

Int J Dev Biol. (2008) 52: 3-7.

Origins and plasticity of neural crest cells and their roles in jaw and craniofacial evolution.

Trainor PA, Melton KR, Manzanares M.

Int J Dev Biol. (2003) 47: 541-53.

Evolution of the Hox/ParaHox gene clusters.

Ferrier DE, Minguillón C.

Int J Dev Biol. (2003) 47: 605-11.

Transcriptional regulation and the evolution of development. Wray GA.

Int J Dev Biol. (2003) 47: 675-84.

Evo-Devo: evolutionary developmental mechanisms.

Brian K Hall

Int. J. Dev. Biol. (2003) 47: 491-495

The morphogenesis of evolutionary developmental biology. Gilbert SF.

Int J Dev Biol. (2003) 47: 467-77.

From development to evolution: the re-establishment of the «Alexander Kowalevsky Medal».

Mikhailov AT, Gilbert SF.

Int J Dev Biol. (2002) 46: 693-8.

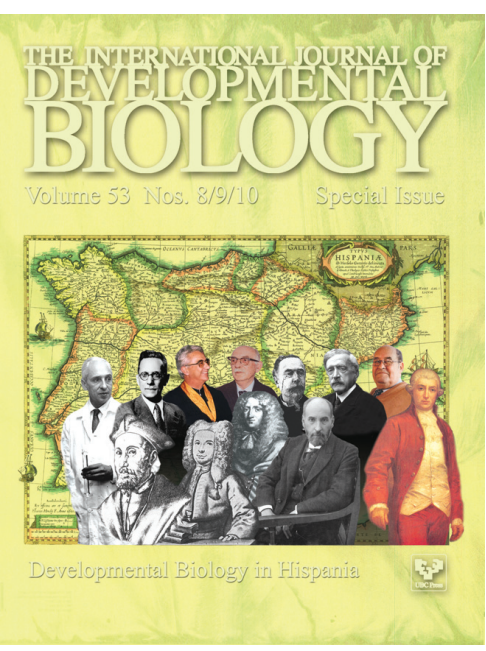

5 yr ISI Impact Factor $(2008)=3.271$

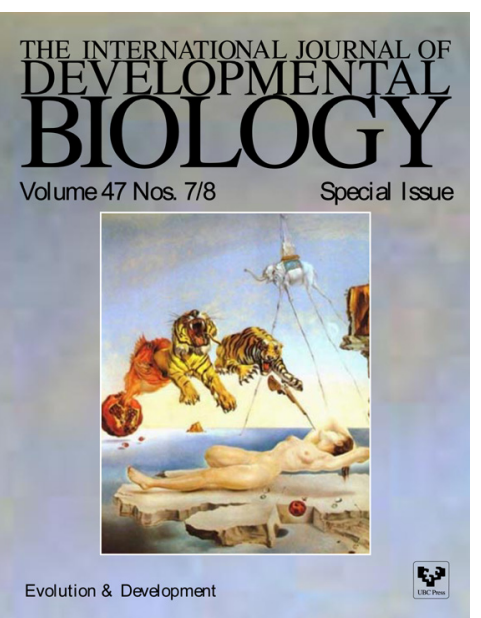

